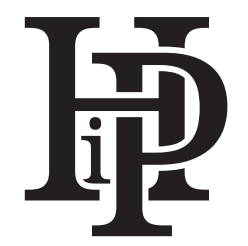

Historia i Polityka

Nr 35(42)/2021, ss. 31-45

www.hip.umk.pl (c) (1) $\Theta$

ISSN 1899-5160, e-ISSN 2391-7652

DOI: http://dx.doi.org/10.12775/HiP.2021.002

Joanna RAK

Uniwersytet im. Adama Mickiewicza, Wydział Nauk Politycznych i Dziennikarstwa, Poznań, Polska

\title{
Autokreacja ról politycznych Komitetu Obrony Demokracji w mitycznym uniwersum polskiej sceny politycznej ${ }^{*}$
}

\author{
The Committee for the Defence of Democracy's Self-Creation of Its Political Roles \\ in the Mythical Universe of the Polish Political Scene
}

\section{- Abstrakt •}

Głównymi celami tego artykułu są identyfikacja mitów ról politycznych, które zostały wykorzystane przez Komitet Obrony Demokracji (KOD) do stworzenia językowego obrazu jego powstania, a także wyjaśnienie znaczenia konfiguracji tych struktur semantycznych dla autokreacji ról politycznych, które okazały się efektywnym bodźcem dla oddolnej mobilizacji przeciwników Prawa i Sprawiedliwości. Zostaną one zrealizowane przy wykorzystaniu analizy źródeł, jakościowej relacyjnej analizy zawartości i typologii mitów. Z kolei cel poboczny artykułu stanowi weryfikacja użyteczności analitycznej narzędzia teoretycznego w postaci typologii mitów, których przedmiotem są role polityczne. Testowi poddano siatkę kategorii teoretycznych obejmującą cztery pary typów idealnych mitów: antropolatryzującego i diabolizującego, teofanijnego i demonizującego, boskiego i diabelskiego mesistesu oraz katechonu i antychrysta. Wykorzystanie tych

\section{- Abstract •}

The article aims to identify the myths of political roles that were used by the Committee for the Defence of Democracy (CDD) to create the language image of its creation and to explain the importance of these semantic structures' configuration for the self-creation of political roles, which proved to be an effective incentive for the grassroots mobilization of the opponents of the Law and Justice party. They will be performed with the source analysis, qualitative relational content analysis, and a typology of myths. The secondary objective of the article is to verify the analytical usefulness of the theoretical tool in the form of a typology of myths created by the criterion of political roles. The research examines the theoretical framework that consists of four pairs of ideal types of myths: anthropolatrizing and diabolizing, theophanic and demonizing, divine and devilish mesistes, katechon and antichrist. The use of these theoretical categories to identify and distinguish the discursive cre-

Artykuł stanowi efekt realizacji projektu badawczego pt. „Kontestacja polityczna a nowa demokracja opancerzona" finansowanego przez Narodowe Centrum Nauki. Numer rejestracyjny grantu: 2018/31/B/HS5/01410. 
kategorii teoretycznych do zidentyfikowania i rozróżnienia dyskursywnych kreacji oraz autokreacji ruchu społecznego pokazało, że dzielą one pole semantyczne mitu roli politycznej w taki sposób, że jego typy idealne są rozłączne i umożliwiają rozpoznanie podstawowych konstruktów semantycznych ról politycznych. Uwidoczniło również, że KOD zaniechał skrajnie pozytywnego i negatywnego wartościowania siebie i swoich oponentów politycznych. Do dyskursywnej autolegitymizacji w systemie politycznym wykorzystał mity teofanijny, boskiego mesistesu i katechonu. Do delegitymizacji rządzących podmiotów politycznych zastosował mity demonizujący i antychrysta. Obraz powstania ruchu był wyrazem poczucia konieczności powstania i działania dobrego katechonu, który powstrzyma antychrysta przed zniszczeniem systemu demokratycznego w Polsce i przyczyni się do ochrony i zachowania jego konstytutywnych wartości.

Słowa kluczowe: ruch społeczny; kontestacja polityczna; mit polityczny; bezpieczeństwo polityczne; dyskurs; demokracja opancerzona; Komitet Obrony Demokracji ations and self-creations of the social movement has shown that they divide the semantic field of the political role myth in such a way that its ideal types are separable and allow us to recognize the basic semantic constructs of political roles. It has also revealed that the CDD did not use the extreme positive and negative valuation of itself and its political opponents. The movement used theophanic, divine mesistes, and katechon myths to self-legitimize discursively in the political system. It employed demonizing and antichrist myths to delegitimize the ruling political subjects. The image of the movement's creation was the expression of the sense of necessity for the emergence and activities of a good katechon which would stop the antichrist from destroying the democratic system in Poland and contribute to the protection and preservation of its constitutive values.

Keywords: social movement; contentious politics; political myth; political safety; discourse; militant democracy; Committee for the Defence of Democracy

\section{Wprowadzenie}

Przedmiotem tego artykułu są dyskursywne manifestacje autokreacji własnej roli politycznej Komitetu Obrony Demokracji (KOD), aktywnego polskiego ruchu społecznego i stowarzyszenia założonego 2 grudnia 2015 r. w celu wyrażenia sprzeciwu wobec działalności podmiotów rządzących, zwłaszcza partii politycznej Prawo i Sprawiedliwość (PiS). Zadeklarowane cele odpowiadały tym realizowanym przez podmioty demokracji opancerzonych i polegały na zachowaniu oraz obronie demokracji przed jej osłabieniem przez wrogów demokracji. Mimo że KOD jest inicjatywą oddolną, utworzoną i kontynuowaną przy wykorzystaniu niewielkich zasobów finansowych i organizacyjnych (Kazimierczuk, 2017; Michalski, 2017), a także kontrowersyjną z powodu niejasności związanych z jej rozliczeniami (Korus, 2017) oraz zarzutami o molestowanie seksualne działaczek (Malinowski, 2017), wciąż pozostaje znaczącą grupą interesu (Dobski, 2017). Działacze KOD-u posługują się zróżnicowanymi formami protestu, aby ukazać 
politykę rządu jako niedemokratyczną, zagrażającą polskim interesom oraz ładowi konstytucyjnemu (Mikulski, 2017). Jednocześnie przedstawiają siebie jako reprezentantów obywateli Polski i obrońców demokratycznych wartości ważnych dla przetrwania polskiego systemu politycznego.

Głównymi celami tego artykułu są identyfikacja mitów ról politycznych, które zostały wykorzystane przez KOD do stworzenia językowego obrazu jego powstania, a także wyjaśnienie znaczenia konfiguracji tych struktur semantycznych dla autokreacji ról politycznych, które okazały się efektywnym bodźcem dla oddolnej mobilizacji przeciwników PiS-u. Dotychczasowe prace badawcze dotyczące KOD-u skupiały się na ukazaniu wizerunku ruchu (Szczepański, 2016; Szafranek, 2017) i jego lidera Mateusza Kijowskiego (Szwed-Walczak, 2017) w artykułach publicystycznych, omawiały jego rolę we współczesnym systemie politycznym Polski (Bugarič, Ginsburg, 2016; Beltran, 2016, s. 8; Kowalewski, 2018; Litwin-Lewandowska, 2017, s. 207; Sztompka, 2016, s. 73) lub analizowały działalność kontestacyjną (Alber, 2016; Drăgulin, 2017; Matthes, 2016a, 2016b; Wiśniewski, 2018). Prezentowane badanie jest pierwszym studium empirycznym myśli politycznej dystrybuowanej przez twórców KOD-u zorientowanym na zbadanie manifestacji świadomości własnych ról w polityce.

Z kolei cel poboczny artykułu stanowi weryfikacja użyteczności analitycznej (Rak, 2017; 2018a) narzędzia teoretycznego w postaci typologii mitów, których przedmiotem są role polityczne. Testowi zostanie poddana siatka kategorii teoretycznych obejmująca cztery pary typów idealnych mitów: antropolatryzującego i diabolizującego, teofanijnego i demonizującego, boskiego i diabelskiego mesistesu oraz katechonu i antychrysta (Rak, 2017; 2018b, s. 8). Wykorzystanie wymienionych kategorii teoretycznych do zidentyfikowania i rozróżnienia dyskursywnych autokreacji ruchu społecznego pozwoli określić, w jakim stopniu wyznaczone antynomiczne typy idealne wypełniają i efektywnie dzielą pole semantyczne mitu roli politycznej.

\section{Założenia metodyczne i teoretyczne}

Pole badawcze poddane analizie to dyskursywne manifestacje autokreacji własnych ról politycznych KOD-u w systemie politycznym Polski. Na etapie pilotażu badania przeanalizowano losowo wybrane wypowiedzi medialne działaczy ruchu ${ }^{1}$

${ }^{1}$ Przekazy medialne pozyskano dzięki systemowi CAST (Content Analysis System for Television) działającemu na Wydziale Nauk Politycznych i Dziennikarstwa Uniwersytetu im. Adama 
oraz zawartość jego oficjalnej strony internetowej i fanpage’a na Facebooku (Komitet Obrony Demokracji, 2018a). Na tej podstawie zdecydowano się na uwzględnienie w badaniu tylko tych tekstów, które służyły działaczom do dystrybucji, a nie redystrybucji myśli politycznej. To kryterium umożliwiło włączenie do korpusu źródeł następujących materiałów: noty informacyjnej $O$ KOD-zie (Komitet Obrony Demokracji, 2018c), Manifestu KOD-u (Komitet Obrony Demokracji, 2018b) i Statutu Stowarzyszenia „Komitet Obrony Demokracji” (Komitet Obrony Demokracji, 2018d). Elementy autokreacji ról politycznych, które wystąpiły w wymienionych tekstach programowych, były konsekwentnie powielane przez reprezentantów KOD-u w wypowiedziach publicznych (Dobski, 2017; Kublik, 2016; Sandecki, 2016). Co istotne, powstały one bezpośrednio po powstaniu ruchu i były źródłem pierwotnej dystrybucji mitu jego powstania. Wyłączenie z korpusu źródeł pozostałych materiałów umożliwiło uniknięcie wielokrotnego analizowania powtarzających się w dyskursie KOD-u struktur semantycznych. Wiązało się to z dążeniem do optymalizacji wykorzystania zasobów do realizacji procesu badawczego. Analiza danych wykluczonych z pola badawczego w tym artykule byłaby wskazana przy rozwiązywaniu problemów badawczych dotyczących poziomów natężenia wykorzystania konkretnych dyskursywnych kreacji ról politycznych przez działaczy ruchu, a więc do kontynuacji analiz zapoczątkowanych $\mathrm{w}$ prezentowanym studium.

Dodatkowo, również na potrzeby optymalizacji procesu badawczego, zdecydowano się na pragmatyczne podejście metodologiczne, czyli jego oparcie o problemy badawcze. Pierwszy z nich wiąże się z potrzebą poznania istoty autokreacji ról politycznych stowarzyszenia i brzmi: jaki był dystans między typami idealnymi mitów ról politycznych a strukturami semantycznymi wykorzystywanymi przez KOD do stworzenia obrazu swego początku? Kolejne problemy badawcze koncentrują się na wyjaśnieniu cech elementów składowych przekazów o powstaniu inicjatywy jako środka do - jak pokazał poziom społecznego poparcia akcji kontestacyjnych ruchu społecznego - efektywnej oddolnej masowej mobilizacji: jakie i dlaczego pewne konfiguracje obrazów ról politycznych ukonstytuowały mit założycielski KOD-u?

Należy tutaj podkreślić, że przedmiotem analizy będą nie tylko umieszczone w dyskursie obrazy własnych ról politycznych. W celu jak najdokładniejszego ich rozpoznania zostaną one dodatkowo przeanalizowane w kontekście relacji, w jakich umieścił je KOD z rolami politycznymi podmiotów rządzących. Wystąpi za-

Mickiewicza w Poznaniu przy wykorzystaniu fraz wyszukiwawczych „KOD” i „Komitet Obrony Demokracji” we wszystkich formach gramatycznych, w jakich mogą wystąpić. 
tem rozróżnienie między własnymi rolami politycznymi a rolami przypisywanymi innym. Te drugie zostaną jednak uwzględnione tylko w takim zakresie, w jakim określają i uwidaczniają cechy ruchu społecznego.

Specyfika źródeł oraz brzmienie problemów badawczych uzasadniają kolejne wybory metodologiczne: metody - analizy źródeł oraz techniki - jakościowej relacyjnej analizy zawartości dokumentów założycielskich KOD-u. Umożliwią one zgromadzenie danych niezbędnych do ustalenia typów mitów ról politycznych dystrybuowanych przez ruch. $\mathrm{Z}$ tekstów zostaną wyodrębnione wszystkie dyskursywne elementy autokreacji - bezpośrednie przez ukazanie swoich ról i pośrednie przez przedstawienie ról politycznych innych podmiotów politycznych pozostających w relacji politycznej z KOD-em.

Narzędziem teoretycznym zastosowanym do przeanalizowania zebranych manifestacji tożsamości jest typologia mitów ról politycznych sformułowana według kryterium stopnia waloryzacji przedmiotu przekazu (Rak, 2017; 2018a). Podczas analizy poddana zostanie ocenie jego użyteczność analityczna do badania myśli politycznej na temat tożsamości czy poczucia jej bezpieczeństwa. Studium to stanowi pierwszy test empiryczny zastanego narzędzia teoretycznego zmodyfikowanego przez dookreślenie specyfiki ról politycznych obrazowanych przez mity.

$\mathrm{Na}$ potrzeby analizy mity definiuje się jako wiązki stereotypów, czyli funkcjonujących w świadomości społecznej uproszczonych i poddanych wartościowaniu obrazów rzeczywistości (Bäcker, 2012, s. 55), w tym przypadku - ról politycznych rozumianych jako podlegający negocjowaniu zbiór praw i obowiązków przysługujących podmiotowi politycznemu. Zaproponowaną definicję stosuje się jako właściwą każdemu typowi idealnemu mitu w obrębie testowanego w badaniu narzędzia - typologii mitów ról politycznych. Nie będzie ona jednak powielana przy omawianiu jej elementów składowych - antynomicznych typów idealnych - w celu uniknięcia powtórzenia prezentacji cech istotnościowych wspólnych wyodrębnionym konstruktom teoretycznym. Zostaną przywołane wyłącznie ich cechy dystynktywne pozwalające na odróżnienie od siebie struktur semantycznych obrazujących konkretne mity ról politycznych.

Testowana typologia mitów składa się z czterech par antynomicznych typów idealnych (diad) różniących się pod względem nasilenia waloryzacji przedmiotu przekazu (Rak, 2017; 2018a). Słowa wartościowanie i waloryzacja oznaczają tutaj poddawanie ocenie, a więc są wolne od konotacji z normatywną aprobatą. Pierwsza para składa się z kategorii odwzorowujących ekstremalnie pozytywne (dobre) i negatywne (złe) cechy ról politycznych (podmiotów je pełniących), odpowiednio ich mitów antropolatryzującego i diabolizującego (Rak, 2017; 2018a). Antropolatria polega na uznaniu człowieka za uosobienie w najwyższym stopniu społecznie 
cenionych cech, wręcz za nowe bóstwo. Z kolei diabolizacja to ukazywanie przedmiotu mitu jako ucieleśniającego w najwyższym stopniu społecznie pogardzane cechy. Mit antropolatryzujący znamionuje maksymalny stopień wartościowania pozytywnego, a diabolizujący - maksymalny stopień waloryzacji negatywnej.

Niższy stopień waloryzacji od mitów ekstremalnych znamionuje teofanię i demonizację (Rak, 2017; 2018a). Teofania opiera się na wysokim stopniu pozytywnego wartościowania roli politycznej. W przeciwieństwie do antropolatrii nie dochodzi zatem do nadania istocie ludzkiej boskich cech istotnościowych. Przeciwieństwem teofanii jest demonizacja opierająca się na założeniu, że przedmiot przekazu jest zły z powodu posiadanych cech. Nie jest jednak skrajnie zły. Mityzacja nie polega na dyskursywnej kreacji przy wykorzystaniu predykatów odzwierciedlających skrajności najlepszych i najgorszych, lecz poprzestaje na ukazaniu dobrych i złych.

Kolejna diada różni się od teofanii i demonizacji niższym poziomem waloryzacji przedmiotu przekazu. Obrazuje ona dwie antynomiczne role polityczne pośredników (Rak, 2017; 2018a). Pierwszy to mit boskiego mesistesu sprowadzający się do przekonania, że człowiek - mesistes, czyli pośrednik - dzięki swoim właściwościom pośredniczy pomiędzy innymi podmiotami politycznymi lub między nimi a materialnymi bądź niematerialnymi przedmiotami. Co istotne, jego zamiary są dobre, z kolei skutki działania - korzystne dla korzystających z usługi mesistesu. Według mitu diabelskiego mesistesu człowiek za sprawą posiadanych cech również pośredniczy, z tą różnicą jednak, że posiada złe zamiary i działa na niekorzyść tego, komu świadczy usługę.

Ostatnia para mitów to typy katechonu i antychrysta (Rak, 2017; 2018a). Warto tu nadmienić, że zgodnie z uzusem językowym występującym w literaturze przedmiotu z zakresu socjologii religii nazwy kategorii teoretycznych zostały napisane małą literą, aby na potrzeby siatki konceptualnej tego artykułu pozbawić je konotacji z chrześcijaństwem. Mit katechonu polega na przypisaniu człowiekowi szczególnych zdolności podtrzymywania istnienia i ochrony świata przed jego zniszczeniem. Powstrzymuje on zło przed destruktywnym oddziaływaniem na strukturę polityczną. Mit katechonu charakteryzuje niższy stopień waloryzacji pozytywnej roli politycznej niż mit boskiego mesistesu. Typem antynomicznym wobec mitu katechonu jest mit antychrysta (Rak, 2017; 2018a; Wielomski, 2016, ss. 359-387). Polega on na przypisaniu człowiekowi unikalnych właściwości przyczyniania się do zniszczenia świata. Innymi słowy, stymuluje on działanie zła, inicjuje i przyspiesza destrukcję doświadczalnej empirycznie rzeczywistości. Typ ten odznacza niższy stopień waloryzacji negatywnej przedmiotu mitu niż mit diabelskiego mesistesu. 
Podsumowując prezentację narzędzia teoretycznego, należy zauważyć, że uwzględnia ono cztery pary typów idealnych mitów: antropolatryzującego i diabolizującego, teofanijnego i demonizującego, boskiego i diabelskiego mesistesu oraz katechonu i antychrysta (Rak, 2017; 2018a). Każdy z nich składa się z cech istotnościowych mitu i dystynktywnych roli politycznej, jaką obrazuje. W kolejnej części artykułu typologia zostanie zastosowana do rozwiązania problemów badawczych oraz oceniona pod względem efektywności analitycznej do analizy tekstów politycznych.

\section{Dyskursywna autokreacja Komitetu Obrony Demokracji}

Dokonana analiza pozwala stwierdzić, że KOD wykorzystał waloryzację pozytywną do określania znaczenia własnych ról politycznych i negatywną do prezentowania swojego oponenta - uogólnionego zbiorowego podmiotu rządzącego. Stworzył tym samym prosty, spójny i uporządkowany obraz rzeczywistości politycznej. Znamienne jest jednak, że ruch ani raz nie posłużył się skrajnym wartościowaniem (zob. Tab. 1.). Brak uświęcania siebie i przekonywania do własnych wartości politycznych jako bezalternatywnych i najlepszych świadczy o umiarkowaniu w zakresie głoszonych poglądów i autokreacji. Brak ekstremizmu uwidocznił się również w niedyskredytowaniu przeciwników politycznych przez ukazywanie go jako uosobienia najgorszych możliwych cech.

Tabela 1. Typy mitów ról politycznych wykorzystanych przez KOD do stworzenia mitu swojego powstania

\begin{tabular}{|c|c|}
\hline Typ mitu roli politycznej & Wykorzystanie mitu do kreacji mitu powstania KOD-u \\
\hline antropolatryzujący & 0 \\
\hline diabolizujący & 0 \\
\hline teofanijny & 15 \\
\hline demonizujący & 13 \\
\hline boskiego mesistesu & 13 \\
\hline diabelskiego mesistesu & 0 \\
\hline katechonu & 13 \\
\hline antychrysta & 13 \\
\hline
\end{tabular}

Źródło: opracowanie własne. 
W dyskursie o powstaniu oddolnej inicjatywy nie pojawiły się także próby stworzenia wizerunku podmiotu rządzącego jako diabelskiego mesistesu. KOD zamiast krytykować jakość tej reprezentacji wyparł ją z dyskursu. Zabieg ten polegał na dyskursywnym odebraniu innym niż nadawca przekazu podmiotom politycznym prawa i zdolności pośredniczenia pomiędzy wielkimi grupami społecznymi, tymiż a ich reprezentantami, a także reprezentowania tychże w organach władzy ustawodawczej, wykonawczej i sądowniczej. Co istotne, ruch wygenerował obraz siebie jako boskiego mesistesu. Nie wyraził bezpośrednio chęci czy nie dokonał dyskursywnego aktu monopolizacji tej roli politycznej, lecz wykorzystywał zwroty pokazujące skalę i zasięg swego działania. Zgodnie z zaprezentowaną narracją to KOD będący wyrazicielem woli ogółu reprezentuje polskie społeczeństwo. Posiadł bowiem wiedzę na temat zasad sprawnego funkcjonowania systemu demokratycznego i jego ochrony przed transpozycją w reżim niedemokratyczny.

Mit powstania KOD-u stanowił konfigurację teofanii, boskiego mesistesu i katechonu jako mitów własnych ról politycznych oraz demonizacji i antychrysta jako mitów ról politycznych pełnionych przez podmioty rządzące. W przekazach wystąpiła niewielka przewaga liczebna kreacji mitu teofanii (15 manifestacji teofanii, a pozostałych typów było po 13). Nie była ona jednak na tyle znacząca, by mówić o dominacji tego typu struktur semantycznych w dyskursie (zob. Tab. 1.). Znacznie ważniejsze dla zrozumienia istoty mitu założycielskiego ruchu są typy relacji pomiędzy mitami wytworzone przez KOD do pokazania własnej roli w polskim systemie politycznym (zob. Tab. 2.).

Tabela 2. Konfiguracje mitów ról politycznych wykorzystanych przez KOD do stworzenia obrazu swojego powstania

\begin{tabular}{|c|c|c|}
\hline $\begin{array}{c}\text { Lp. } \\
\text { konfiguracji }\end{array}$ & $\begin{array}{c}\text { Typy mitów własnych ról } \\
\text { politycznych wykorzystanych } \\
\text { przez KOD do stworzenia mitu } \\
\text { swojego powstania }\end{array}$ & $\begin{array}{c}\text { Typy mitów ról politycznych } \\
\text { podmiotów rządzących } \\
\text { wykorzystanych przez KOD } \\
\text { do stworzenia mitu swojego } \\
\text { powstania }\end{array}$ \\
\hline 1. & mit katechonu & mit antychrysta \\
\hline 2. & mit boskiego mesistesu & mit demonizujący \\
\hline 3. & mit teofanijny & - \\
\hline
\end{tabular}

Źródło: opracowanie własne.

Stowarzyszenie zachowało liczebną równowagę w zakresie wykorzystania negatywnego i pozytywnego waloryzowania o najniższym poziomie nasilenia odpowiednio obcych i własnych ról politycznych. Zastosowało bowiem 13 przed- 
stawień mitu katechonu i 13 antychrysta do stworzenia mitu założycielskiego (zob. Tab. 1.). Współwystępowały one w opisach ról politycznych tworzonych przez ruch (zob. Tab. 2.). Konstruowanie mitu KOD-u jako katechonu polegało na przypisaniu sobie szczególnych zdolności podtrzymywania istnienia systemu demokratycznego w Polsce i jego ochrony przed przekształceniem w reżim niedemokratyczny: „Komitet Obrony Demokracji został stworzony, by walczyć z łamaniem prawa przez rządzących w naszym kraju" (Komitet Obrony Demokracji, 2018c). Zgodnie z zaprezentowaną narracją, potrzeba pełnienia wskazanej roli politycznej - „walki z łamaniem prawa” - dyskursywnie legitymizowała ruch społeczny. Jednocześnie delegitymizowała podmioty rządzące, których działalność była niezgodna z obowiązującym prawem. Odwołanie się do wspólnoty „naszego kraju" (Komitet Obrony Demokracji, 2018c) wzmocniło siłę przekazu przez ukazanie skali działania katechonu - całej Polski.

Obraz mitu tego podmiotu politycznego, który chroni państwo przed zniszczeniem został wzmocniony charakterystyką oponenta politycznego uczynionego przedmiotem mitu antychrysta nierespektującego prawa stanowiącego fundament systemu politycznego: „Demokracja w Polsce jest zagrożona. Działania władzy, jej lekceważenie prawa oraz demokratycznego obyczaju zmuszają nas do wyrażenia stanowczego sprzeciwu. Nie chcemy Polski totalitarnej, zamkniętej dla myślących inaczej niż każe władza, nie chcemy Polski pełnej frustracji i żądzy rewanżu" (Komitet Obrony Demokracji, 2018b). Zabieg ten sprowadzał się do przypisania uogólnionemu zbiorowemu rządzącemu podmiotowi politycznemu unikalnych właściwości przyczyniania się do niszczenia demokracji w Polsce. Jego działania polegające na lekceważeniu prawa i wartości państwa demokratycznego zostały uznane za zagrażające aktualnemu reżimowi politycznemu, bo prowadzące do zmiany jego cech istotnościowych i transpozycji w totalitaryzm. Oznacza to, że antychryst przeciwstawiony katechonowi stymulował działanie zła, inicjował i przyspieszał destrukcję tego, co według narracji powinno być zachowane.

W obrazie starcia sił katechonu i antychrysta pojawiało się także odwołanie do Konstytucji Rzeczypospolitej Polskiej, której obrona była ważnym motywem przewodnim działalności kontestacyjnej KOD-u: „Nie zgadzamy się na łamanie Konstytucji i wprowadzanie, z nadużyciem mechanizmów demokracji, rządów autorytarnych" (Komitet Obrony Demokracji, 2018b). Ruch opowiedział się przeciwko zmianie demokracji w totalitaryzm oraz autorytaryzm. Jego nadana sobie rola polityczna strażnika prawa i obrońcy konstytucji odzwierciedlała istotę działań mających na celu powstrzymanie podmiotu politycznego spełniającego cechy istotnościowe antychrysta przed nieakceptowalnym naruszeniem zastanego porządku politycznego. 
Wykorzystanie dwóch mitycznych figur katechonu i antychrysta do stworzenia mitu początku KOD-u dało nieskomplikowany intelektualnie, spójny i uporządkowany obraz rzeczywistości politycznej, w której występował konflikt między podmiotami rządzonymi a rządzącymi. Posiadały one jasno sprecyzowane antynomiczne role polityczne o przypisanych jednoznacznie złych lub dobrych celach. Pojawienie się zła w postaci zagrożenia - antychrysta - dyskursywnie legitymizowało powstanie i działalność katechonu.

Mit boskiego mesistesu został użyty 13 razy (zob. Tab. 1.) i stworzony przez umieszczenie przez KOD siebie w roli pośrednika między obywatelami a źródłem wiedzy o efektywnym funkcjonowaniu systemu politycznego w Polsce. Typ ten wystąpił pojedynczo lub w konfiguracji z mitem demonizującym siły antydemokratyczne uosabiane przez podmioty rządzące (zob. Tab. 2.). KOD przypisał sobie zadanie przypominania wyborcom o prawach i obowiązkach wynikających w funkcjonowania w ramach systemu demokratycznego: „[Komitet Obrony Demokracji został stworzony,] by przypomnieć wszystkim obywatelom, że mieszkamy w państwie demokratycznym i że demokracji powinniśmy ze wszystkich sił bronić" (Komitet Obrony Demokracji, 2018c). W micie tym widoczne są elementy politycznej kontrakulturacji, w szczególności w wyrazach woli niedopuszczenia do jakościowej zmiany demokracji. Była to manifestacja świadomości posiadania i realizacji misji edukacyjnej oraz obrony obecnego rodzimego reżimu politycznego.

Kolejnym typem przejawu postrzegania siebie jako pośrednika - boskiego mesistesu - była autokreacja obrazu wyraziciela woli ogółu: „Chcemy żyć w społeczeństwie neutralnym światopoglądowo, przeciwdziałać łamaniu zasad praworządności, nadużyciom władz, przekraczaniu przez nią swoich uprawnień oraz kompetencji” (Komitet Obrony Demokracji, 2018c). W tym przypadku KOD wykorzystał pierwszą osobę liczby mnogiej do stworzenia wspólnoty celów i przekonań. Istnienie ruchu dyskursywnie legitymizował przez wyrażenie potrzeby reprezentowania podmiotu rządzonego doświadczającego relatywnych deprywacji w zakresie wolności wyrażania światopoglądu, przestrzegania zasad praworządności i sprawowania ról politycznych przez uogólnione zbiorowe podmioty rządzące. Do wzmocnienia kreacji mitu pośrednika realizującego moralnie dobre funkcje KOD wykorzystał mit demonizujący rządzących. W analizowanym dyskursie pojawił się on 13 razy w konfiguracji z boskim mesistesem (zob. Tab. 1.). W tychże kreacjach podmioty rządzące zostały uznane za złe i obwinione o to, że w sposób nieakceptowalny ingerują w zastany system polityczny. Innymi słowy, przyczyniają się one do wystąpienia w społeczeństwie zbiorowych względnych deprywacji na poziomie ochrony, kreacji i dystrybucji dóbr publicznych. 
Najliczniej reprezentowany typ, bo 15 razy (zob. Tab. 1.), mit teofanijny uwidocznił się w pozytywnym wartościowaniu własnej roli politycznej KOD-u przez ukazywanie jego zadań. Nie wykorzystano go w parach z waloryzującymi negatywnie mitami obrazującymi podmioty rządzące (zob. Tab. 2.). Kompletny katalog celów, które były pojedynczo lub w różnych konfiguracjach przywoływane w pozostałych dokumentach (np. „Naszym celem jest propagowanie postaw sprzyjających rozwojowi demokratycznego państwa prawa. Chcemy upowszechniać i chronić wolności i prawa człowieka oraz swobody obywatelskie, działać na rzecz popularyzacji wiedzę [sic!] o demokratycznym ustroju państwa prawa, a także budować społeczeństwo obywatelskie" (Komitet Obrony Demokracji, 2018c).) został umieszczony w statucie stowarzyszenia i zostanie tu przywołany w całości zamiast pojedynczych referencji z poszczególnych dokumentów: „Cele Stowarzyszenia [to]: 1) rozwijanie i propagowanie postaw i działań sprzyjających zachowaniu i rozwojowi demokratycznego państwa prawnego, 2) wspieranie i rozwijanie idei państwa neutralnego światopoglądowo, 3) wspieranie i rozwój idei społeczeństwa obywatelskiego, promowanie postaw i zachowań obywatelskich, 4) upowszechnianie i ochrona wolności i praw człowieka oraz swobód obywatelskich, 5) działalność na rzecz integracji oraz rozwijania kontaktów i współpracy między społeczeństwami, 6) przeciwdziałanie łamaniu zasad demokracji i praworządności, w tym m.in. nadużyciom władz państwowych i samorządowych, przekraczaniu uprawnień i kompetencji, 7) działalność mająca na celu upowszechnianie wiedzy o demokratycznym ustroju państwa prawa, urzeczywistniającego zasady sprawiedliwości społecznej, zapewniającego wolności i prawa człowieka i obywatela oraz bezpieczeństwo obywateli - określonym w Konstytucji Rzeczypospolitej Polskiej z dnia 2 kwietnia 1997 r., w duchu, w jakim powstała, i zasadach, na jakich się opiera, 8) troska o demokrację, prawa obywatelskie i rozwój społeczeństwa obywatelskiego" (Komitet Obrony Demokracji, 2018d). Wszystkie dążenia KOD-u zwerbalizowane w przywołanym katalogu polegały na promocji, ochronie i podtrzymywaniu wartości demokratycznych w Polsce. Rola ta była spójna z pozostałymi - katechonu i boskiego mesistesu.

\section{Podsumowanie}

Analiza uwidoczniła, że KOD wykorzystał bezpośrednio mity teofanijny, boskiego mesistesu i katechonu do dyskursywnej kreacji własnej roli politycznej w polskim systemie politycznym. Mitów demonizującego i antychrysta użył pośrednio do autokreacji, mianowicie zastosował je do pokazania ról politycznych swoje- 
go oponenta - uogólnionego zbiorowego podmiotu rządzącego, oraz umieścił je w relacji do autoprzedstawień. Konfiguracja tych struktur semantycznych stworzyła prosty, spójny i uporządkowany obraz rzeczywistości politycznej, w której dochodzi do starcia sił dobra i zła, konfliktu politycznego między rządzonymi a rządzącymi. Przeświadczenie o konieczności wejścia w pierwszą z wymienionych ról legło u podstaw kreacji mitu powstania stowarzyszenia i było stale wykorzystywane do jego legitymizacji w dyskursie. Dobro reprezentował ruch społeczny promujący, broniący oraz zachowujący wartości demokratyczne. Z kolei ówczesnych rządzących ukazano jako uosobienie zła. Zgodnie z narracją stowarzyszenia, zagrażali oni demokracji w Polsce przez niszczenie jej fundamentów i implementowanie do niej cech reżimów niedemokratycznych - autorytarnych oraz totalitarnych. KOD stworzył katalog celów wyznaczających zakres przypisanych sobie ról politycznych. Podporządkował je misji właściwej celom podmiotów demokracji opancerzonej, powstrzymania realizacji działań sił niedemokratycznych, co - jak pokazał poziom społecznego poparcia akcji kontestacyjnych ruchu - okazało się efektywnym bodźcem dla oddolnej mobilizacji przeciwników PiS-u.

W wyniku analizy materiałów źródłowych pozytywnie zweryfikowano użyteczność analityczną narzędzia teoretycznego w postaci typologii mitów, których przedmiotem są role polityczne. Siatka kategorii teoretycznych obejmująca cztery pary typów idealnych mitów: antropolatryzującego i diabolizującego, teofanijnego i demonizującego, boskiego i diabelskiego mesistesu oraz katechonu i antychrysta umożliwiła zidentyfikowanie i rozróżnienie dyskursywnych autokreacji i kreacji ruchu społecznego. Krytyczna analiza właściwości wspomnianych typów idealnych poparta wynikami badania empirycznego pokazuje, że wyznaczone antynomiczne kategorie wypełniają pole semantyczne mitu roli politycznej. Dodatkowo diady te efektywnie dzielą pole semantyczne mitu roli politycznej, ponieważ żadne pojedyncze do niego odwołanie nie spełniło cech dystynktywnych więcej aniżeli jednego typu idealnego.

Test typologii pokazał jednak, że poszczególne typy idealne mitów ról politycznych, zwłaszcza boskiego mesistesu, mogą być zróżnicowane pod względem charakteru pośredniczenia pomiędzy podmiotami politycznymi. Warto byłoby zatem przeprowadzić dodatkowe analizy empiryczne materiałów źródłowych bardziej licznych i w wyższym stopniu zdywersyfikowanych w zakresie odwołań do ról politycznych. Pozwoliłoby to na subtypologizację kategorii teoretycznych, a w konsekwencji - stworzenie bardziej efektywnego narzędzia do precyzyjniejszego analizowania mitów. Nie jest wykluczone przy tym, że wystąpiłyby dodatkowe kryteria, poza rozpoznanym w tym badaniu, umożliwiające subtypologizację już sformułowanych typów idealnych. 


\section{Bibliografia:}

Alber, I. (2016). Doing Civil Society in Post-Socialist Poland. Triangulation of Biographical Analysis and Discourse Analysis. Przegląd Socjologiczny, 65(4), 91-110.

Bäcker, R. (2012). Polityczność mitów historycznych. W: M. Kołodziejczak, R. Rosicki (red.). Od teorii do praktyki politycznej. Ksiegga jubileuszowa dedykowana profesorowi Zbigniewowi Blokowi z okazji 40-lecia pracy naukowej i 70-lecia urodzin (ss. 49-57). Poznań: Wydawnictwo Naukowe Wydziału Nauk Politycznych i Dziennikarstwa Uniwersytetu im. Adama Mickiewicza.

Beltran, M.R. (2016). Emerging Issues: Breaking News: Polish Legislators Make Waves with New Broadcast Media Law, EU Human Rights Concerns on the Rise. University of Baltimore Journal of International Law, 5(1), 129-135.

Bugarič, B., Ginsburg, T. (2016). The Assault on Postcommunist Courts. Journal of Democracy, 27(3), 69-82. DOI: 10.1353/jod.2016.0047.

Dobski, M. (2017.05.08). Piotr Wieczorek: KOD-u już nie ma. Pobrane z: https://www.rp.pl/ Komitet-Obrony-Demokracji/170509423-Piotr-Wieczorek-KOD-u-juz-nie-ma.html.

Drăgulin, A.I. (2017). The European Union's Democratic Paradigm in the Post-Communist Countries of Eastern Europe. Revista Romana de Studii Eurasiatice, 13(1/2), 173-186.

Kazimierczuk, A. (2017.05.02). \#RZECZoPOLITYCE Kijowski: Nawalit caty KOD. Pobrane z: https://www.rp.pl/Komitet-Obrony-Demokracji/170509893-RZECZoPOLITYCE-Kijowski-Nawalil-caly-KOD.html.

Komitet Obrony Demokracji (2018a). Fanpage KOD-u na Facebooku, 2015-2018. Pobrane z: https://www.facebook.com/KomitetObronyDemokracji/.

Komitet Obrony Demokracji (2018b). Manifest KOD-u. Pobrane z: https:/www.ruchkod.pl/wp-content/uploads/2016/12/20170223120005085_0001.pdf.

Komitet Obrony Demokracji (2018c). O KOD-zie, 2015. Pobrane z: https://www.ruchkod.pl/o-kod-zie/.

Komitet Obrony Demokracji (2018d). Statut Stowarzyszenia „Komitet Obrony Demokracji”, Tekst jednolity Statutu Stowarzyszenia Komitet Obrony Demokracji, zawierajacy zmiany uchwalone przez: Nadzwyczajne Walne Zebrania Cztonków z dnia 8 maja 2016 roku, 5 czerwca 2016 roku, 19 czerwca 2016 roku. Krajowy Zjazd Delegatów z dnia 28 maja 2017 roku, Nadzwyczajny Krajowy Zjazd Delegatów z dni 31.06-01.02.2018 roku. Pobrane z: https://www.ruchkod.pl/statut/.

Korus, J. (2017.07.11). Obywatele RP uczą się na btędach KOD, rozliczając każdą ztotówkę. I pokazuja faktury. Pobrane z: https://www.newsweek.pl/polska/spoleczenstwo/obywatele-rp-rozliczaja-kazda-zlotowke-i-pokazuja-faktury-darowizn/gez26gv.

Kowalewski, M. (2018). Emergent Political Spaces in the Post-Socialist City: Solidarity Square, Szczecin. Space and Polity, 22(3), 328-341. DOI: 10.1080/13562576.2018. 1555959.

Kublik, A. (2016.05.27). Gtównym celem KOD jest budowa spoteczeństwa obywatelskiego. Kompromis ws. Trybunatu pozwoli nam się wreszcie tym zająć. Pobrane z: http://wyborcza. $\mathrm{pl} / 1,75398,20143039$,glownym-celem-kod-u-jest-budowa-spoleczenstwa-obywatelskiego.html. 
Litwin-Lewandowska, D. (2017). Konflikt polityczny na przykładzie sporu o Trybunał Konstytucyjny. Annales Universitatis Mariae Curie-Sktodowska, sectio K-Politologia, 23(2), 207-222. DOI: 10.17951/k.2016.23.2.207.

Malinowski, P. (2017.04.15). Molestowanie w KOD? Zarzuty koordynatorki. Pobrane z: https:/www.rp.pl/Komitet-Obrony-Demokracji/170419327-Molestowanie-w-KODZarzuty-koordynatorki.html.

Matthes, C.-Y. (2016a). Comparative Assessments of the State of Democracy in EastCentral Europe and Its Anchoring in Society. Problems of Post-Communism: Anchors Lost? The State of Democracy in East-Central Europe, 63(5-6), 323-334. DOI: 10.1080/10758216.2016.1201771.

Matthes, C.-Y. (2016b). The State of Democracy in Poland after 2007: Analyzing the Linkage between Economic Development and Political Participation. Problems of Post-Communism: Anchors Lost? The State of Democracy in East-Central Europe, 63(5-6), 288-299. DOI: 10.1080/10758216.2016.1201770.

Michalski, C. (2017.01.18). Czy KOD zostanie zabity, zanim nauczy się polityki?. Pobrane z: https://www.newsweek.pl/opinie/mateusz-kijowski-i-kryzys-w-kod-czy-kijowski-powinien-odejsc-z-komitetu-obrony/41whyjf.

Mikulski, J. (2017.08.21). KOD przedstawia wtasne 21 postulatów. Pobrane z: https:// www.rp.pl/Komitet-Obrony-Demokracji/170839695-KOD-przedstawia-wlasne-21postulatow.html.

Rak, J. (2017). Siatka typologiczna mitów jako narzędzie do badania myśli politycznej. W: J. Marszałek-Kawa, K. Kakareko (red.). Azjatyckie pogranicza kultury i polityki (ss. 191-226). Toruń: Wydawnictwo Adam Marszałek.

Rak, J. (2018a). The Typological Framework of Myths as a Tool for Studying Political Thought. World Political Science, 14(2), 235-256. DOI: 10.1515/wps-2018-0009.

Rak, J. (2018b). Theorizing Cultures of Political Violence in Times of Austerity: Studying Social Movements in Comparative Perspective. London, New York: Routledge.

Sandecki, M. (2016.11.21). "Nie damy się deportowac”. Protest KOD-u przed biurem PiS, a tam nagle poset Śniadek. Pobrane z: http://trojmiasto.wyborcza.pl/trojmiasto/1,35612, 21011314,nie-damy-sie-deportowac-protest-kod-u-pod-biurem-pis-w-gdyni.html.

Szczepański, J. (2016). Datum i novum wojny w polskich tygodnikach opinii - spór władzy i opozycji wokół Komitetu Obrony Demokracji. W: M. Dajnowicz, A. Miodowskiego (red.). Polityka i politycy w prasie XX i XXI wieku (ss. 154-164). Białystok: Wydawnictwo HUMANICA Instytut Studiów Kobiecych.

Szafranek, R. (2017). Elitaryzm w ruchach społecznych: społeczeństwo liberalne Richarda Rorty'ego a medialny dyskurs dotyczący Komitetu Obrony Demokracji. W: M. Marczewska-Rytko, D. Maj (red.). Nowe ruchy spoteczne (ss. 265-272). Lublin: Wydawnictwo Uniwersytetu Marii Curie-Skłodowskiej.

Sztompka, P. (2016). The "Demand Side" of Populism: The Case of Poland. W: A. Martinelli (red.). Beyond Trump: Populism on the Rise (ss. 73-92). Milano: Edizioni Epoké - ISPI.

Szwed-Walczak, A. (2017). Komunikowanie ugrupowań politycznych na Facebooku w trakcie kryzysu sejmowego na przełomie 2016 i 2017 roku. Polityka i Społeczeństwo, 4(15), 117-133. DOI: 10.15584/polispol.2017.4.9. 
Wielomski, A. (2016). W poszukiwaniu Katechona: teologia polityczna Carla Schmitta. Radzymin: Wydawnictwo Von Borowiecky.

Wiśniewski, B.M. (2018). Pluralistic Forms of Ensuring the Social and Democratic Balance as Part of Sustainable Development. W: T. Zieliński, I. Sagan, W. Surosz (red.). Interdisciplinary Approaches for Sustainable Development Goals (ss. 43-49). Cham: Springer. 